\title{
SPATIAL DEPENDENCE, FOREIGN INVESTMENT AND PRODUCTIVITY SPILLOVERS IN NEW EU MEMBER STATES
}

\author{
Nebojša Stojčić ${ }^{a *}$ and Edvard Orlićb \\ $a_{*}$ Department of Economics and Business Economics, University of Dubrovnik, Dubrovnik, \\ Croatia. Linkedin; ORCiD; ResearchGate; Email: nstojcic@unidu.hr \\ ${ }^{b}$ Department of Accounting, Finance and Economics, Bournemouth University, \\ Bournemouth, United Kingdom.Email: eorlic@bournemouth.ac.uk \\ Geolocation information: Central and Eastern Europe
}

\begin{abstract}
This paper presents new empirical evidence on the impact of FDI technology spillovers on the productivity of domestic firms in manufacturing and services in Central and East European regions over 2007-2011 period. The complex impact of FDI is separated into direct and indirect effects while accounting for spatial feedback effects. Findings suggest that FDI presence generates negative intra and inter-regional market stealing effects on direct rivals and positive spillovers on downstream firms. The effects are larger from FDI in neighbouring regions and increase with distance
\end{abstract}

Keywords: FDI, TFP, regions, spatial analysis, CEEC

JEL: F23, R12, R15 


\section{INTRODUCTION}

It has long been acknowledged that firms from advanced countries possess superior knowledge and technology, making them more efficient and productive than domestic firms in advancing countries (Castellani and Zanfei, 2006). Therefore, policy makers continuously invest significant efforts in the attraction of foreign direct investment (FDI) through various types of incentives hoping that the accumulation of FDI will induce technological upgrading and productivity growth through technology and knowledge diffusion. While theoretical arguments for FDI-induced pecuniary and technology spillovers are well established (Smeets, 2008), empirical specifications relating to domestic firms' TFP and foreign presence provide simply averaged impact resulting from various channels, thus potentially hiding different mechanisms and variations of FDI spillovers.

The literature on FDI spillovers focused on heterogeneity of foreign and domestic firms (Monastiriotis and Alegria, 2011; Javorcik and Spatareanu, 2011) but it provides limited discussion on mechanisms causing its spatial differentiation. In this paper we propose to use geography to determine the pattern of technology diffusion and therefore the ability of domestic firms to expropriate spillovers. Innovation (Audreutsh and Feldman, 2004) and agglomeration literature (Puga, 2010) emphasize proximity and density for knowledge spillovers. Given the similarity of the underlying mechanisms of FDI spillovers and agglomeration economies it is expected that co(location) matters for skill upgrading, information sharing and knowledge absorption through linkages with multinational companies (MNCs) (Ning et al., 2016).

Our study explores intraregional and interregional effects of foreign firm presence on regional (NUTS3) productivity of indigenous firms in eight Central and East European (CEE) countries. Technological abilities in these countries are relatively weak and the bulk of FDI went to metropolitan areas and western regions potentially contributing to the polarization and disparities (Smetkovski and Wojcik, 2012). The analysis is based on a rich panel of firms in 217 NUTS3 regions of the Czech Republic, Hungary, Poland, Slovak Republic, Slovenia, Croatia, Romania and Bulgaria covering the 2007-2011 period. Results from Spatial Durbin Model (SDM) reveal that FDI generates positive productivity effects on downstream firms within and across regions while horizontal spillovers are negative. These effects become stronger from MNCs from neighbouring regions and increase with distance. 
The study enriches the existing body of knowledge in several ways. It examines the role of spatial proximity in the manufacturing and service sector. FDI in services now accounts for almost 65 per cent of the total worldwide inward FDI stock (UNCTAD, 2014) and is likely to differ from manufacturing industries in production, spatial concentration and transmission of knowledge (Orlic et al., 2018). Merlevede and Purice (2016) suggest that distance may have a different effect on FDI spillovers through vertical and horizontal channels. Apart from spatial concentration, there may be important spatial interactions shaped by feedback loops (i.e., from one location to its neighbours, and then neighbours' neighbours, and finally back to the original location indirectly) among indigenous firms and between indigenous firms and MNCs (Lin and Kwan, 2016). This further complicates the identification and interpretation of results. The method we employ is capable of separately identifying direct and indirect effects and explore whether diffusion patterns of different spillover channels change at greater distances while taking into account interregional feedback effects of FDI spillovers. Finally, we investigate whether TFP gains are subject to regions' absorptive capacity.

The paper is structured as follows. The role of geographical distance in facilitating or inhibiting knowledge spillovers from FDI is dealt with in section two. Productivity measurement, the data and empirical model are laid down in section three. In section four, we present results of an investigation. Section five discusses policy implications and directions for further research.

\section{FDI PRODUCTIVITY SPILLOVERS AND THE ROLE OF GEOGRAPHY}

\section{Horizontal and vertical spillovers}

FDI is often regarded as one of major sources of technology and knowledge inflows to the recipient countries (Crespo and Fontoura, 2007). Domestic firms can benefit from horizontal spillovers such as imitation and reverse engineering of MNCs' know-how, organizational and marketing practices (Findlay, 1978). Foreign firms also provide indigenous workforce with training, education and work experience that can increase productivity of domestic firms through worker mobility (Markusen and Trofimenko, 2009). Finally, increased competition stimulates adoption of new technology and management practices and introduction of more cost-conscious management (Aitken and Harrison, 1999). However, these externalities depend on investment of domestic firms in purchasing, adoption and development of knowledge (Orlic et al., 2018). 
The improvements in productivity of domestic firms may also come through supplier-buyer vertical interactions with foreign counterparts. Input quality presents competitive advantage for foreign firms for which they may be willing to share technical and managerial knowledge, product design, quality procedures and financial management experience with domestic suppliers through backward linkages (Zanfei, 2012). Productivity spillovers can take place through knowledge transfer, higher product quality requirements and technology upgrading (Mariotti et al., 2015). Similarly, productivity improvements may occur through forward linkages between indigenous customers and foreign suppliers. On the one hand, products, processes and technologies sold to downstream domestic firms often embody superior knowledge (Orlic et al., 2018). On the other hand, increased competition in upstream sectors may force all input suppliers to increase efficiency, thus leading to better quality and cheaper inputs to downstream firms (Markusen, and Venables, 1999).

However, foreign entry may crowd out local firms. Horizontal spillovers can be minimized through increased protection of intellectual property and trade secrecy by MNCs (Javorcik, 2004). In addition, increased market supply capacity exerts downward pressure on prices while higher wages paid by foreign firms make it difficult for local firms to retain their most valuable employees or recruit qualified labour (Spencer, 2008). MNCs can draw away domestic demand by offering better and higher quality products and services. Entry of foreign firms can increase concentration in upstream industry, increase prices and reduce choice of inputs for domestic buyer firms.

It must be noted that coefficients measuring FDI spillovers may capture other effects than knowledge externalities or spillovers (Keller, 2010). In case of horizontal spillovers the standard measure usually summarizes positive effects of knowledge spillovers through reverse engineering and labour mobility from MNCs to domestic firms on one hand and negative pecuniary spillovers from market stealing effects on the other hand. Similarly, the literature is not able to separate FDI spillovers from vertical linkages that occur through voluntary knowledge transfer from externalities in the form of increased demand for intermediate inputs (Newman et al., 2015). Following Orlic et al. (2018) our estimation of productivity spillovers captures the net effects of pure "not paid for" technological 
externalities that shift firm production function and pecuniary externalities that arise from competition effects and changes in input prices. ${ }^{1}$

\section{Spatial proximity and sector heterogeneity}

The localization theory of knowledge spillovers posits that being near knowledge providers (MNCs) within the same region or neighbouring regions helps domestic firms to tap the knowledge from foreign firms' more easily (Audretsch and Feldman, 2004; Acs et al., 2013). However, improvements in information and communication technology (ICT) have lowered the barriers for knowledge diffusion across space enabling the wider spread of demonstration effects (Girma, 2005). Negative market stealing effects could easily spread to the entire country in highly integrated markets characterised by diverse distribution channels. However, given the limited labour mobility the net effect of horizontal knowledge spillovers may still be limited to narrow geographical scope (Lin and Kwan, 2016). In addition, MNCs may prefer suppliers located in wider geographical areas to benefit from high quality inputs while on the other hand they may develop local linkages to minimize transaction costs and facilitate communication with a domestic supplier or distributor.

The final outcome depends on the characteristics of the sectors involved. Nowadays, manufacturing industries source inputs from various places and make many regions and cities diversified rather than specialised (Krugman, 2011). Being open to international competition, they are more likely to flourish in regions that offer an economic base characterised by a variety of related activities. Further, assets of manufacturing firms favour physical proximity with related knowledge, human capital and technology (Mariotti et al., 2015). On the other hand, many services are predominantly non-tradable and require proximity to local demand (Basile et al., 2017). This is particularly true of CEEC' capital cities which are converging at a higher rate due to their networked, service-oriented economies (Dogaru et al., 2011). Yet, with advancements in ICT the mobility of knowledge (the principal asset of services) increases, and the geographical proximity may be less relevant. Crone (2012) argues that short meetings and temporary co-location are sufficient to satisfy face to face communication.

\section{Empirical evidence}

\footnotetext{
1 Separating knowledge spillovers and competition effects from FDI would require information on firms' position in product market and technology space (Bloom et al., 2013). However, such approach requires detailed data, not available in our dataset.
} 
Studies that address spatial diffusion of FDI spillovers find negative intra and inter-regional horizontal spillovers whereas intra- and inter-regional vertical spillovers are positive (Javorcik and Spatareanu, 2008; Jordaan, 2008b). Halpern and Murakozy (2007) find positive horizontal spillovers across regions, but negative one within regions in Hungary. In contrast, several studies find that spillovers are mostly localized (Driffield, 2006 for the UK; Jordaan, 2008a for Mexico). More recently, Merlevede and Purice (2016) find limited effect of distance on horizontal spillovers, but a positive and significant intra-regional backward spillovers upon immediate entry of foreign firms, but only in above medium productivity regions. Less productive regions seem to benefit from inter-regional backward spillovers. Mariotti et al. (2015) find that spillovers are strong in knowledge intensive sectors, but proximity is not relevant.

Second set of studies examine spatial heterogeneity. For example, Monastiriotis and Jordaan (2010) have shown for the case of Greece that spillovers are maximised in areas with weaker agglomerations and lower levels of development. Altomonte and Colantone (2008) suggest that FDI spillovers are different in core and peripheral regions and thus magnify regional disparities in Romania. Similar findings are reported in Monastiriotis (2016) who finds that although investment from the EU raises the productivity of domestic firms in EU-28 they come at the expense of exacerbating regional disparities due to FDI spillovers being positive only in capital-city regions. The receptivity to spillovers seems to be greater in regions with more diverse industrial structures than in narrowly specialised areas (Wang et al., 2016).

Another weakness of the existing body of knowledge lies in origin of its findings. Over recent years, and building on work of LeSage and Pace (2009), the literature has come to understanding that inter - regional spillover effects hide far greater complexity than initially thought. The effect of spillovers from source regions is not unidirectional. It generates feedback loops to initial region through various interregional transmission channels that do not involve solely interactions between foreign and domestic firms but also those between domestic firms in different regions. Existing empirical studies have relied on conventional econometric techniques incapable of capturing direct and indirect effects which casts doubt over existing results. Our study relies instead on spatial econometric framework and, as one of the earliest papers in the field, fills the above gap. 


\section{EMPIRICAL STRATEGY}

\section{Model}

A general model that allows us to estimate FDI spillover effects within and between regions is based on Sun et al. (2010). More specifically we model TFP as:

$$
A_{i t}=A_{0} e^{\beta F D I_{i t}+\theta w_{i j} F D I_{j t}} \prod_{j \neq i}^{N} A_{j t}^{\rho w_{i j}} e^{\varepsilon_{i t}}
$$

Where $A_{i t}$ depends not only on its own initial level $A_{i 0}$ which represents productivity effects of time-invariant location factor, but also on intra and inter-regional FDI spillovers $F D I_{i t}$ and $F D I_{j}$, respectively, and on the neighbours' level $A_{j t}$. Productivity levels and FDI spillovers in other regions, spill over to region $i$ with an elasticity of $\rho w i j$ and $\theta w i j$ respectively, where $w_{i j}$ depends on the distance between regions defined by spatial matrix.

Taking logs of Eq. (1) and expressing it in matrix notation we get:

$A_{t}=A_{0}+\varepsilon F D I_{i t}+\theta W F D I_{j t}+\rho W A_{t}+\varepsilon_{i t}$

Where $A_{t}=\ln \left(\mathrm{A}_{\mathrm{it}}\right)$ is $(\mathrm{Nx} 1)$ vector of region-specific logged productivity estimates, $A_{0}=$ $\ln \left(A_{0 i}\right)$ an $(\mathrm{Nx} 1)$ vector of region-specific constants, and $F D I_{i t}$ the vector of region-specific FDI spillovers. Similarly, $F D I_{j t}=$ is the vector of inter-regional FDI spillovers. Finally, W= $\left(w_{i j}\right)$ is a row standardized $(\mathrm{NxN})$ spatial weight matrix with main diagonal elements $\left(w_{i i}\right)$ equal to zero and off diagonal elements $0 \leq w_{i j}<1, \mathrm{i} \neq \mathrm{j}$ and $\varepsilon_{i t}$ is the error term.

\section{Data and variables definition}

The primary source of firm level data comes from Amadeus database provided by Bureau van Dijk containing financial information and other firms specific variables such as geographical location, industry codes and detailed ownership information for a very large number of firms in each of the 217 NUTS3 regions from eight CEECs (the Czech Republic, Croatia, Bulgaria, Hungary, Poland, Slovak Republic, Romania and Slovenia) in the 2006-2011 period ${ }^{2}$. Our final sample contains a panel of 1,531,665 firm year observations of which 78,416 are foreign owned.

\footnotetext{
${ }^{2}$ An Online Appendix to this paper provides a detailed description of the dataset (Figures A1 and A2), its summary statistics (Table A2) and representativeness (Tables A3-A5).
} 


\section{TFP estimation}

Starting from linearized Cobb Douglas production function for firm $i$ in time period $t$ :

$\ln \left(Y_{i t}\right)=\beta_{k} \ln \left(K_{i t}\right)+\beta_{l} \ln \left(L_{i t}\right)+\beta_{m} \ln \left(M_{i t}\right)+\omega_{i t}+v_{i t}$

where $\mathrm{Y}_{\mathrm{it}}, \mathrm{K}_{\mathrm{it}}, \mathrm{M}_{\mathrm{it}}$ denote natural logarithms of deflated sales, tangible fixed assets and material costs, respectively while $\mathrm{L}_{\mathrm{it}}$ is the $\log$ of the number of employees for firm $i$ at time $t$ we estimate firm TFP. Composite error term $\left(\omega_{i t}+v_{i t}\right)$ includes firm specific productivity denoted by $\left(\omega_{i t}\right)$ and $\left(\mathrm{v}_{\mathrm{it}}\right)$ which represents measurement error or unanticipated productivity shock. In estimation of TFP we adopt Gandhi et al. (2016) approach that is capable of controlling for simultaneity and value added bias and can be used to estimate a wide range of functional forms ${ }^{3}$.

To achieve our research objective, we aggregate firm level TFP to NUTS3 level. Regional $T F P_{r t}$ is a sum of weighted firm-level TFP of domestic firms $i$ in region $r$ and industry $j$ at time $t$, with the weights being the output shares $\left(q_{i j r t}\right)$ of the corresponding firms located in the underlying region. Specifically, regional TFP is calculated as:

$\operatorname{lnTFP} P_{r t}=\sum_{i} \frac{q_{i j r t}}{\sum_{i} q_{i j r t}} \ln T F P_{i j r t}$

\section{Definition of FDI spillovers}

Spillovers from foreign firms on the productivity of domestic firms are defined as horizontal, vertical backward and vertical forward. Following standard practice, horizontal spillovers for each industry-region-year are defined as: ${ }^{4}$

$$
\operatorname{Horz}_{j r t}=\frac{\sum_{i \epsilon j}\left(\text { Foreign }_{i j t} * Y_{i j r t}\right)}{\sum_{i \epsilon j} Y_{i j r t}}
$$

where $Y_{\text {iirt }}$ is the output (measured as revenue) produced by firm $i$ in industry $j$ in region $r$ and year $t$. We denote as Foreign any firm for which the share of direct foreign participation by a single investor is at least $10 \%$. By using the share of foreign firm's output, we consider the relative size of foreign activity in a defined industry and geographical scope. Horizontal spillovers measure the potential positive demonstration and imitation effects arising from

\footnotetext{
${ }^{3}$ The advantage of this estimator over conventional ones is discussed in greater length in Section A1 of online appendix to this paper.

${ }^{4}$ When calculating horizontal spillover measure, we included all firms in the database regardless of whether or not they were included in the TFP estimation. In the estimation of the latter, we follow data cleaning strategy described in Online Appendix (Section A1).
} 
reverse engineering and competition effects on one hand, and negative market stealing effects on the other hand.

Vertical spillovers measures examine the link between MNCs and corresponding domestic suppliers (backward) and customers (forward). Since information on individual firms' inputs is not available, we follow the standard practice in the literature (Javorcik, 2004; Orlic et al., 2018) by making use of information provided in the input output tables obtained from the World Input-Output database (WIOD). The firm's input from other firms (or its sales to other firms) are approximated by intermediate consumption using country's input-output tables. Information on inter-industry sourcing from the WIOD is then combined with information on sales of foreign firms in each sector and region calculated in Eq. (6). By using time-varying annual input-output tables we are able to relax the assumption of the same sourcing behaviour of firms over time found in previous studies.

The vertical backward and forward spillovers from the presence of foreign firms in manufacturing and services are defined as:

Backward $_{j r t}=\sum_{k=1}^{K} \alpha_{j k t}$ Horizontal $_{k r t}$

Forward $_{\text {jrt }}=\sum_{l=1}^{L} \gamma_{j l t}$ Horizontal $_{l r t}$

Where technical coefficient $\alpha_{j k t}$ is the proportion of industry $j$ 's output supplied to industry $k$ in period $t$ weighted by share of foreign firms' output in industry $k$ and region $r$. Hence, the backward linkage captures spillovers between MNCs and local suppliers. Technical coefficient $\gamma_{j l t}$ is the proportion of industry $l$ 's inputs purchased from industries $j$ at time $t$. The forward linkage is a proxy for spillovers between MNCs and their local clients. The larger the presence of MNCs in upstream sectors $l$ and the larger the output sold to other firms the higher is the value of the variable.

The technical coefficients $\alpha_{j k t}$ and $\gamma_{j l t}$ are calculated for domestic intermediate consumption excluding final uses, imports and export, thus relaxing the assumption that MNCs employ domestic inputs in the same proportion as imported inputs. While both types of inputs can increase TFP of domestic firms, MNCs may source different inputs in host country (Barrios et al., 2011). The computation of technical coefficients for vertical spillovers departs from the standard approach in the literature and includes inputs supplied within the same industry as recently suggested by Leanerts and Merlevede (2016). 
Our spillover variables are defined at industry-region level, however the empirical estimation is conducted at the regional level only. For this reason, the regional average values of above introduced measures enter the model. Such approach, previously applied by Lin and Kwan (2016) and Nguyen et al. (2016) inevitably results in a loss of industry-level information but it enables us to properly model the nature of inter-regional spillover effects including spatial feedback loops. In addition, spatial econometric analyses require data to have a balanced structure over time.

\section{Control variables}

Since TFP is a function of many factors, Eq. (2) is augmented by including other regional characteristics. The effects of FDI spillovers are likely to differ with respect to the level of regional specialization. To control for this effect, two frequently used measures of agglomeration externalities are employed, namely urbanization and localization economies. The former is defined as the percentage of all firms within the region in the total number of firms in country for each year. As such it captures the between industrial externalities. Within industrial externalities are captured with variable defined as the average percentage of firms from the same industry within the total number of firms in each region.

We also control for absorptive capacity that enables firms to identify, assimilate and apply knowledge from external sources (Cohen and Levintahl, 1990). With that in mind, we include firms' investments in intangible assets (IA), which have been insufficiently taken into account in traditional productivity estimations (Syverson, 2011). Battisti et al. (2012) argue that intangible assets provide a more comprehensive measure of effort that firms incur to improve their market position and revenues as they include R\&D costs, absorptive capability and marketing, design and technical expenditure. It is expected that MNCs will transfer tacit knowledge embodied in IA if regions already possess an appropriate amount of knowledge. For this reason, we include a share of the intangible asset in total fixed assets in the region $r^{5}$.

Apart from intangible assets, we control for the level of human capital as it is recognized that more educated workforce improves the production capabilities of the region as they are more productive and better at creating new technologies (Castellani and Pieri, 2013) and in

\footnotetext{
${ }^{5}$ In Amadeus the intangible fixed assets are capitalized and encompass R\&D expenditures, patents, copyrights, software, employee training, trademarks and expenditures on similar costs. Other components such as computerized information, organizational capital and economic competencies are more difficult to estimate which represents a major challenge in quantifying productivity effects of intangibles. In addition, certain components of intangibles can be complements or substitutes which may further mask their effects on productivity.
} 
innovation and learning process (Meyer and Sinani, 2009). We assume that wages are positively correlated with skills as in Wagner (2012) who demonstrated that the average wage in a firm is a useful proxy variable for the qualification of the employees. Therefore, we proxy for human capital by using the average wage paid by firms from our sample in each of analysed regions.

\section{Empirical specification}

By using spatial econometric models, spillovers between regions can be explicitly considered and thus reduce omitted variable bias (LeSage and Pace, 2009). The latter issue is particularly relevant for FDI spillovers as knowledge can be transferred through various mechanisms that are hard to capture. Following Ertur and Koch (2007) these omitted variables are also spatially correlated and must be captured using a spatial lag specification in the error term or in the dependent variable. We assume that omitted variables are endogenous to TFP, so that Spatial Durbin Model seems to be more appropriate (Elhorst, 2013).

The baseline specification used to examine the effects of FDI spillovers on domestic firm's TFP is therefore:

$\operatorname{lnTFP}_{i t}=c_{0}+\rho \sum_{j=1}^{n} w_{i j} \operatorname{lnTFP}_{j t}+\beta_{1}$ horizontal $_{i t-1}+\beta_{2}$ forward $_{i t-1}+\beta_{3}$ backward $_{i t-1}+$ $\theta_{1} \sum_{j=1}^{n} w_{i j}$ horizontal $_{j t-1}+\theta_{2} \sum_{j=1}^{n} w_{i j}$ forward $_{j t-1}+\theta_{3} \sum_{j=1}^{n} w_{i j}$ backward $_{j t-1}+$ $\gamma_{4}$ urbanization $_{i t}+\gamma_{5}$ localization $_{i t}+\gamma_{6} I A R_{i t}+\gamma_{7} H C_{i t}+\theta_{4} \sum_{j=1}^{n} w_{i j} I A R_{i t}+$ $\delta_{8}\left(\right.$ horizontal $\left._{i t-1} * I A R_{i t}\right)+\delta_{9}\left(\right.$ forward $\left._{i t-1} * I A R_{i t}\right)+\delta_{10}\left(\right.$ backward $\left._{i t-1} * I A R_{i t}\right)+$ $\theta_{5}\left(\sum_{j=1}^{n} w_{i j} I A R_{i t} * w_{i j}\right.$ horizontal $\left._{j t-1}\right)+\theta_{6}\left(\sum_{j=1}^{n} w_{i j} I A R_{i t} * w_{i j}\right.$ forward $\left._{j t-1}\right)+$ $\theta_{7}\left(\sum_{j=1}^{n} w_{i j} I A R_{i t} * w_{i j}\right.$ backward $\left._{j t-1}\right) \vartheta_{t}+u_{i t}$

where dependent variable $\ln T F P_{i t}$ is natural logarithm of TFP of domestic firms for region $i$ in period $t$. The expression $\sum_{j=1}^{n} w_{i j} \operatorname{lnTFP} P_{j t}$ is the interaction effect of the dependent variable with the dependent variables of other units while $w_{i j}$ is the $\mathrm{i}, \mathrm{j}$-th element of a prespecified nonnegative $\mathrm{NxN}$ spatial weights matrix W. The spatial autoregressive coefficient $(\rho)$ measures the impacts of change in the TFP of other regions (e.g. region $j$ ) on the level of TFP in region $i$. Similarly, $\beta$ and $\theta$ are intra-regional and inter-regional elasticities of horizontal, forward and backward FDI spillovers and their interactions with intangible fixed assets. Due to interaction between these variables we also spatially lag the latter variable. Given that countries in the sample have been affected by the global financial crisis and some of them joined the European Union in 2007, following Elhorst (2013) we included also country and 
time dummies in our estimations $\vartheta_{t}$ to account for potential structural changes. Finally, $u_{i t}$ is disturbance term that is independent and identically distributed normal random variable.

The empirical model is estimated using the Maximum Likelihood method to control for the simultaneity raised when spatially weighted dependent variable is introduced into the equation following Elhorst (2014). Horizontal and vertical FDI spillovers are lagged one period which is motivated by expectation of the realisation of knowledge spillovers from FDI does not happen instantaneously but may take time to be absorbed (Merlevede and Purice, 2016). In addition, following previous research taking lags mitigates possible endogeneity problems (Halpern and Murakozy, 2007; Ning et al., 2016).

Four weight matrices $\boldsymbol{w}_{i j}$ are employed to assess the robustness of our findings. As a starting point, a contiguity matrix is used with spatial correlation limited to first neighbours only. We then extend spatial correlation to second order neighbours also (neighbours of neighbouring regions) who are assigned value of 1 in the second specification and value of 0.5 in the third specification. Finally, we allow for full spatial correlation through inverse distance normalized matrix where the non-zero off-elements $\boldsymbol{w}_{i j}$ represent the degree of spatial interaction between regions, giving more weight to nearby observations than to distant observations. The elements of the spatial weight matrix are standardized so that the elements in each row add to one.

\section{SPATIAL PRODUCTIVITY DYNAMICS}

As a first step of empirical analysis we look into spatial dependence in productivity through means of the global Moran's I index (Table 1). Findings for all years signal the spatial clustering of highly productive regions at one end of the spectrum and least productive counterparts at the opposite end.

(Table 1 about here)

Visual presentation of these findings (Figure 1) for 2007 and 2011 reveals several patterns of spatial clustering. Spatial clustering of highly productive regions is observed in the Czech Republic, Slovenia and Slovakia (HH group). North-West of Croatia, central Romania, Polish areas attractive to foreign investors such as Lodz, Poznan or Krakow and major metropolitan areas of other countries contain highly productive regions surrounded with low productive environment (HL group). By 2011, across Hungary, Slovenia, Croatia and Bulgaria we 
observe patterns of productivity upgrading from either LL or LH groups towards HL and $\mathrm{HH}$ ones. The opposite appears to be the case in Romania where thirteen regions have been characterised with declining regional productivity. As these regions were surrounded with less productive counterparts it is highly probable that these negative effects have prevailed.

(Figure 1 about here)

Overall, the transition of many regions from low towards high productive groups signals the presence of positive spillover effects, something that we further explore in a spatial model that incorporates both spatial interactions across regions and spatial technology diffusion of FDI.

\section{RESULTS OF ESTIMATION}

We now move to discuss the results of our estimation. LeSage and Pace (2009) show that the interpretation of parameter estimates in spatial models might lead to erroneous conclusions. A change in region $i$ as of time $t$, will generate direct impact on the region itself (i.e. intraregional impact $\left.\partial \mathrm{TFP}_{\mathrm{it}+\mathrm{S}} / \partial \mathrm{x}_{\mathrm{it}}\right)$ and potentially indirect impact or spillover effect on other region $j$ (i.e. inter-regional impact $\partial \mathrm{TFP}_{\mathrm{jt}}+\mathrm{s} / \partial \mathrm{x}_{\mathrm{it}}$ ). Hence, a change of FDI spillovers in region $i$ affects $\mathrm{TFP}_{\mathrm{jt}}$ in region $j$, which in turn affects $\mathrm{TFP}_{\mathrm{it}}$ in region $i$ via the spatial autoregressive term. These feedback loops arise because region $i$ is considered as a neighbour to its neighbours, so the impact passing through neighbouring regions will create a feedback impact on region $i$ itself (Lin and Kwan, 2016). For this reason, the results in Table 2 and subsequent tables are presented as average direct and indirect effects. In order to further provide support to our theoretical predictions we examined usual model specification tests which confirm our expectations regarding model specification. These can be found in an online appendix to this paper (Table A1).

\section{Results for the baseline model}

Moving to the estimates of FDI spillovers, on average we find that foreign firms presence in upstream sectors induce positive effects on local firms in downstream sectors, whereas local firms in the same sector suffer negative effects. Hence, access to inputs of better quality, superior knowledge embodied in products, processes and technologies all improve productivity of downstream domestic firms. This finding is partly in line with the results of Newman et al. (2015) for Vietnamese manufacturing firms. If we assume that FDI output share in upstream sector in all regions (column 4) increases by 10 percent of the sample 
mean, domestic private firms' TFP on average would increase by 0.08 percent due to direct impact from FDI presence within the same region. The magnitudes of interregional spillovers, however, are several times higher. Domestic firms' TFP in downstream sector would on average increase by 0.28 percent due to indirect spillovers from increase in FDI presence in the neighbouring regions, after accounting for impacts from spatial feedback loops.

When we gradually increase the number of neighbours the effects of spatial forward FDI spillovers become larger suggesting that co-location in near proximity of foreign suppliers is not necessary as other forms of proximity, such as cognitive or organizational may be more relevant (Mariotti et al., 2015).

Negative horizontal spillovers in narrow and wide geographical scope suggest that several mechanisms might be in place. Foreign firms may prevent technology leakage, thus limiting demonstration effects. In addition, best employees may be drawn to MNCs with higher wages reducing efficiency of domestic firms. Finally, greater technological distance between foreign and domestic firms and the weak ability of domestic firms to internalize spillovers may drive our findings. Because of lower absorptive capacity, it is more likely that horizontal spillovers will be negative due to pecuniary externalities in the form of market stealing. As MNCs operate nationwide, this may explain increasing negative competition effects in wider geographical areas due to highly integrated markets (Lin and Kwan, 2016). The extent of negative horizontal spillovers increases when the range of neighbouring regions expands as the coefficient of interregional spillovers decreases from -0.10 to -0.21 when spatial matrix is not truncated.

\section{(Table 2 about here)}

We also find positive (negative) and significant direct and indirect effects of urbanization (localization) economies suggesting that between-industrial externalities have a beneficial effect on productivity of domestic firms. With regard to absorptive capacity, the results suggest that quality of human capital is important in the implementation and adoption of existing technologies. This is in line with Bournakis et al. (2018) and underline the importance for local economies to have the necessary levels of absorptive capacity to transfer these capabilities into tangible productivity gains.

Finally, non-significant coefficients on backward spillovers deserve some comment. Subsidiaries of foreign companies often rely on supplier networks and technologies of parent 
companies in host countries (Jindra et al., 2009). Hence, local suppliers may end up supplying standardized inputs with limited potential for technology spillovers (Mariotti et al., 2015). Non-significant backward spillovers may signal the lack of absorptive capacity in domestic upstream firms (Hanousek et al., 2011). Technological and human capital disparities prevent domestic firms to identify, convert and exploit needs of foreign customers to their own advantage. Tsai (2009) notes that even in cases of strong connections between upstream and downstream firms, performance gains will be absent if the absorptive capacity is too low. Cost-saving orientation of subsidiaries may also hinder local capability upgrading (Miozzo et al., 2012). Moreover, meta-analysis by Havranek and Irsova (2011) shows that the choice of dependent variable and estimation technique may result in small and insignificant positive effects of backward spillovers. Our findings should be seen in light of the above arguments.

\section{Sectoral heterogeneity of FDI spillovers}

As argued in Section 2.2.1 geographical proximity can have different effects on manufacturing and service industries. Tables 3 and 4 provide intraregional (direct) and interregional (indirect) effects for manufacturing and services, respectively.

(Table 3 about here)

Analogous to baseline specification, we obtain positive forward and negative horizontal effects of foreign direct investment in both manufacturing and services. The magnitude of effects follows the same path as that in the baseline specification and increases as spatial matrices take into account a greater number of regions. Regarding agglomeration externalities we find identical effects across sectors. The results reveal positive effects of urbanization and negative effects of localization economies within both narrow and a wider geographical area. In manufacturing, negative localization economies may reflect the global trend of manufacturing activity to spread out (Krugman, 2011). The results suggest that local knowledge spillovers in manufacturing are outweighed by insufficient sharing of intermediate inputs and tougher competition. On the other hand, it seems that diverse industry structure and economic density of activities increase the chances of knowledge spillovers with positive effects on TFP, although relatively limited in space.

(Table 4 about here) 


\section{CONCLUSION AND POLICY RECOMMENDATIONS}

Previous studies on FDI spillovers across a variety of national contexts have placed emphasis on the conditions which influence their magnitude (Crespo and Fontoura, 2007). However, little emphasis has been placed on spatial dependence and interaction of firms in space. In addition, the estimation of FDI productivity spillovers has generally focused on manufacturing industries. In contrast to previous studies, this paper analyses FDI spillovers in spatial econometric framework and investigates whether the effects vary across sectors. The inclusion of services in the analysis is particularly relevant in the context of CEECs due to numerous Western MNCs moving their service operations to the region over the last decade. Consequently, these countries emerged as locations for increased fragmentation and reallocation of specific business functions.

Overall, our findings indicate that the presence of MNCs in the same sector exhibits negative effects on productivity of local rivals across both sectors, while it creates positive spillovers for their customers and in service sector suppliers. The effects of spillovers are not localised, but their magnitude increases over space. The exception from this are services where beneficial effects on suppliers are of highly local nature. This paper provides important methodological contribution as it shows that FDI spillovers are subject to spatial dependency. Therefore, previous studies disregarding spatial correlation and thus the importance of interaction among local firms must be treated with caution.

This paper yields some important implications for policy makers. FDI spillovers are susceptible to influence from policy makers particularly in the context of CEECs where a variety of incentives have been put in place to influence the location of MNCs. This has been part of their industrial strategies and increased efforts to boost the competitiveness of the service sector. Understanding how FDI spillovers contribute to increased productivity of domestic firms and their competitiveness on international markets will enhance policy makers potential. The results in general point to positive vertical and negative horizontal effects. Therefore, it is important to consider regional absorptive capacity of firms to explore, assimilate, exploit and apply foreign knowledge. In that way, they can increase the embeddedness of MNCs and foster ties with them through backward or forward linkages.

Policy makers should make every reasonable effort to promote collaboration and knowledge sharing given that between-industrial economies contribute to the productivity. Preferential 
treatment of foreign firms could contribute to creation of industrial clusters of highly productive firms so that spatial externalities benefit other firms as well. Local policy makers offering special incentives to attract FDI may also be necessary. However, more specialized regions are less flexible to adjust its economic structure to external shocks. This is especially true for manufacturing industries which require a more diversified economic structure (Basile et al., 2017). Therefore, the focus should be on MNCs' strategies and devise tailor made regional policies and incentives that increase their local embeddedness.

While our research offered several contributions to existing literature on FDI spillovers there are several research directions that could be explored further. First, further study should explore the heterogeneity of both foreign and domestic firms in more detail. This would shed more light on the mechanisms and magnitudes of FDI spillover channels. Second, it would be of great interest to explore how regional absorptive capacity moderates FDI spillovers. This would shed more light on some of the results presented in this paper, namely negative effects of backward linkages in the manufacturing sector. In addition, it would show how interactive exchange of knowledge contributes to embeddedness of MNCs within regions. Third, future research should explore the role of agglomeration externalities on firm TFP in more detail. Recent developments emphasize that between sector knowledge spillovers are best captured through the notion of related variety (Boschma, 2005; Basile et al., 2017). In that way, researchers could identify which levels and types of diversity matter for knowledge spillovers.

\section{REFERENCES}

Acs, Z. J., Audretsch, D. B., and Lehmann, E. E. (2013). The knowledge spillover theory of entrepreneurship. Small Business Economics, 41(4), 757-774.

Aitken, B. J. and Harrison, A. E. (1999). Do Domestic Firms Benefit from Direct Foreign Investment? Evidence from Venezuela. American Economic Review, 89(3), 605-618.

Altomonte, C. and Colantone, I. (2008). Firm Heterogeneity and Endogenous Regional Disparities. Journal of Economic Geography, 8(6), 779-810.

Audretsch, D. B., and Feldman, M. (2004). Knowledge spillovers and the geography of innovation. In J. V. Henderson and J. F. Thisse (Eds.), Handbook of urban and regional economics (pp. 2713-2739). Amsterdam: Elsevier.

Barrios, S., Görg, H. and Strobl, E. (2011). Spillovers through backward linkages from 
multinationals: Measurement matters! European Economic Review, 55(6), 862-875.

Basile, R., Pittiglio, R. and Reganati, F. (2017). Do agglomeration externalities affect firm survival? Regional Studies, 51(4), 548-562.

Bloom, N., Schankerman, M., \& van Reenen, J. (2013). Identifying technology spillovers and market share rivalry. Econometrica, 81(4), 1347-1393.

Boschma, R. (2005). Proximity and innovation: A critical assessment. Regional Studies, $39,61-74$.

Castellani, D. and Pieri, F. (2013). R\&D offshoring and the productivity growth of European regions. Research Policy, 42(9), 1581-1594.

Castellani, D. and Zanfei, A. (Eds.) (2006). Multinational firms, innovation and productivity. Cheltenham: Edward Elgar.

Cohen, W. and Levinthal, D. (1990). Absorptive capacity: a new perspective on learning and innovation. Administrative Science Quarterly, 35(1), 128-152.

Crespo, N. and Fontoura, M. P. (2007). Determinant Factors of FDI Spillovers - What Do We Really Know? World Development, 35(3), 410-425.

Crone, M. (2012). Re-thinking 'peripherality' in the context of a knowledge-intensive service-dominated economy. In: Danson, M. and De Souza P. (Eds), Regional Development in Northern Europe: Peripherality, Marginality and Border Issues (pp. 4964). London: Routledge.

Dogaru, T., van Oort, F., and Thissen, M. (2011). Agglomeration economies in European regions: perspectives for objective-1 regions. Journal of Economic and Social Geography, 102, 486-494.

Driffield, N. (2006). On the search for spillovers from FDI with spatial dependency. Regional Studies, 40, 107-119.

Elhorst, J.P. (2014). Matlab software for spatial panels. International Regional Science Review 37, 389-405.

Elhorst, J.P. (2013). Spatial Panel Models. In Fischer, M.M. and Nijkamp, P. (Eds.) Handbook of Regional Science (pp. 1637-1652), Berlin: Springer-Verlag.

Ertur, C. and Koch, W. (2007). Growth, technological interdependence and spatial externalities: theory and evidence. Journal of Applied Econometrics, 22(6), 1033-1062.

Findlay, R. (1978). Relative Backwardness, Direct Foreign Investment, and the Transfer of Technology: A Simple Dynamic Model. Quarterly Journal of Economics, 92(1), 1-16.

Gandhi, A., S. Navarro, and D. Rivers (2016). On the identification of production functions: How heterogeneous is productivity? Working paper, University of WisconsinMadison. 
Girma, S. (2005). Absorptive capacity and productivity spillovers from FDI: a threshold regression analysis. Oxford Bulletin of Economics and Statistics, 67(3), 281-306.

Halpern, L. and Murakozy, B. (2007). Does distance matter in spillover? Economics of Transition, 15(4), 781-805.

Hanousek, J., Kočenda, E. and Maurel, M. (2011). Direct and indirect effects of FDI in emerging European markets: A survey and meta-analysis. Economic Systems, 35(3), 301322.

Havranek, T. and Irsova, Z. (2011). Estimating vertical spillovers from FDI: Why results vary and what the true effect is. Journal of International Economics, 85(2), 234-244.

Irsova, Z. And Havranek. T. (2013). Determinants of Horizontal Spillovers from FDI: Evidence from a Large Meta-Analysis. World Development, 42(C), 1-15.

Javorcik, B. (2004). Does Foreign Direct Investment Increase the Productivity of Domestic Firms? In Search of Spillovers through Backward Linkages. American Economic Review, 94(3), 605-627.

Javorcik, B.S. and Spatareanu, M. (2008). To share or not to share: Does local participation matter for spillovers from foreign direct investment? Journal of Development Economics, 85, 194-217.

Javorcik, B.S. and Spatareanu, M. (2011). Does it matter where you come from? Vertical spillovers from foreign direct investment and the origin of investors. Journal of Development Economics, 96(1), 126-138.

Jindra, B., Giroud, A. and Scott-Kennel, J. (2009). Subsidiary roles, vertical linkages and economic development: Lessons from transition economies. Journal of World Business, 44, 167-179.

Jordaan, J.A. (2008a). Intra and inter-industry externalities from foreign direct investment in the Mexican manufacturing sector: New evidence from Mexican regions. World Development, 36(12), 838-2854.

Jordaan, J.A. (2008b). Regional foreign participation and externalities: New empirical evidence from Mexican regions. Environment and Planning A, 40, 2948-2969.

Keller, W. (2010). International trade, foreign direct investment, and technology spillovers. Handbook of the Economics of Innovation, 2, 793-829.

Krugman, P. (2011). The New Economic Geography, now middleaged. Regional Studies, $45,1-7$.

Leanerts, K. and Merlevede, B. (2016). Supply chain fragmentation, input-output tables and spillovers from foreign direct investment. Economic Systems Research, 28(3), 315332. 
LeSage, J.P. and Pace, R.K. (2009). Introduction to Spatial Econometrics. London and New York: CRC Press.

Lin, M. and Kwan, Y. K. (2016). FDI technology spillovers, geography, and spatial diffusion. International Review of Economics and Finance, 43, 257-274.

Mariotti, S. Mutinelli, M., Nicolini, M. and Piscitello, L. (2015). Productivity Spillovers from Foreign Multinational Enterprises to Domestic Manufacturing Firms: To What Extent Does Spatial Proximity Matter? Regional Studies, 49(10), 1639-1653.

Markusen, J. R., Trofimenko, N. (2009). Teaching locals new tricks: Foreign experts as a channel of knowledge transfers. Journal of Development Economics, 88(1), 120-131.

Markusen, J.R. and Venables, A.J. (1999). Foreign Direct Investment as a catalyst for industrial development. European Economic Review, 43(2), 335-356.

Merlevede, B. and Purice, V. (2016). Distance, time since foreign entry and productivity spillovers from foreign direct investment. Papers in Regional Science, 95(4), 775-801.

Meyer, K.R. and Sinani, E. (2009). When and where does foreign direct investment generate positive spillovers? A meta-analysis. Journal of International Business Studies, 40, 1075-1094.

Miozzo, M., Yamin, M. and Ghauri, P. N. (2012). Strategy and structure of service multinationals and their impact on linkages with local firms. The Service Industries Journal, 32, 1171-1191.

Monastiriotis, V. (2016). Institutional proximity and the size and geography of foreign direct investment spillovers: Do European firms generate more favourable productivity spillovers in the European Union neighbourhood? Environment and Planning C, 00, 1-22.

Monastiriotis, V. and Alegria, R. (2011). Origin of FDI and intra-industry domestic spillovers: The case of Greek and European FDI in Bulgaria. Review of Development Economics. 15(2), 326-339.

Monastiriotis, V. and Jordaan, J.A. (2010). Does FDI promote regional development? Evidence from local and regional productivity spillovers in Greece. Eastern Journal of European Studies. 1(2), 139-164.

Newman, C., Rand, J., Talbot, T. and Trap, F. (2015). Technology transfers, foreign investment and productivity spillovers. European Economic Review, 76, 168-187.

Ning, L., Wang, F. and Li, J. (2016). Urban innovation, regional externalities of foreign direct investment and industrial agglomeration: Evidence from Chinese cities. Research Policy, 45, 830-843.

Nguyen, P. A., Phan, T. H., Simioni, M. (2016). Productivity convergence in Vietnamese manufacturing industry: evidence using a spatial Durbin model. In: Van-Nam Huynh, Vladik Kreinovich, Songsak Sriboonchitta, (eds.)., Causal inference in econometrics (p. 603-619). Studies in Computational Intelligence, Springer International Publishing. 
Orlic, E., Hashi, I. and Hisarciklilar, M. (2018). Cross-sectoral FDI spillovers and their impact on manufacturing productivity. International Business Review, 27(4), 777-796.

Puga, D. (2010). The magnitude and causes of agglomeration economies. Journal of Regional Science, 50(1), 203-219.

Smeets, R. (2008). Collecting the Pieces of the FDI Knowledge Spillovers Puzzle. World Bank Research Observer, 23(2), 107-138.

Smetkovski, M. and Wojcik, P. (2012). Regional Convergence in Central and Eastern European Countries: A Multidimensional Approach. European Planning Studies, 20(6), 923-939.

Spencer, J.W. (2008). The impact of multinational enterprise strategy on indigenous enterprises: Horizontal spillovers and crowding out effects in developing countries. Academy of Management Review, 33(2), 341-361.

Sun, L., Hong, E. and Li. T (2010). Incorporating technology diffusion, factor mobility and structural change into cross-region growth regression: An application to China. Journal of Regional Science, 50(3), 734-755.

Tsai, K-H. (2009). Collaborative networks and product innovation performance: Toward a contingency perspective. Research Policy, 38(5), 765-778.

Zanfei, A. (2012). Effects, Not Externalities. European Journal of Development Research. 24(1), 8-14. 